\title{
Agriculture Journalism Brings Employment in India
}

\author{
Avinash Sharma ${ }^{1 *}$, Monoj Sutradhar ${ }^{2}$, Sheelawati Monlai ${ }^{1}$ and Nirupa Kumari ${ }^{3}$ \\ ${ }^{1}$ Arunachal University of Studies, Namsai, Arunachal Pradesh, India \\ ${ }^{2}$ Bidhan Chandra Agricultural University, Mohanpur, West Bengal, India \\ ${ }^{3}$ Department of Botany, Patna University, India \\ *Corresponding author
}

\begin{tabular}{l} 
Ke y w o r d s \\
$\begin{array}{l}\text { Agricultural } \\
\text { Journalism, } \\
\text { Communication } \\
\text { technology, GDP }\end{array}$ \\
\hline Article Info \\
$\begin{array}{l}\text { Accepted: } \\
\text { 16 August } 2018 \\
\text { Available Online: } \\
\text { 10 September } 2018\end{array}$ \\
\hline
\end{tabular}

A B S T R A C T
The present review discussed about agricultural journalism produces opportunity into agriculture sector. The agriculture journalism would receive opportunity into agriculture radio station, agriculture information and broadcasting. The agriculture journalism will provide education or employment from Agriculture Journalism University and agriculture corporate. The agriculture radio station, the agriculture information and broadcasting, Agriculture Journalism University and agriculture corporate would be implemented at each state of India. This institute, university and corporate will generate employment in writing, advertisement, broadcasting, photojournalism, editing and design. This would provide opportunity to agriculture journalism degree holder, Agriculture degree holder in the state. The agriculture profession would function in block, village and district of the state. The agriculture journalism will thrive crop production output, national GDP, overcome farmer problem, farm machinery and implements, farmer lifestyle and doubling of farmer income. The agriculture journalism will mitigate unemployment in agriculture through communication technology. This would bring revolution into agriculture academic system and opportunity at future in India.

\section{Introduction}

Agricultural journalism is an emerging discipline and extension activities that offers agriculture information to Indian farmers and students. The agricultural journalism was initiated at mid $19^{\text {th }}$ century in India. Three books were published on weather, European agriculture and agriculture implements. The founder of Aligarh Muslim University Sir Sayed Ahmad Khan recommended letter to Aligarh collector Mr. J H Princip for establishing scientific society. The first agricultural journalism society was established at Aligarh Muslim University in 1859 year. They provided agricultural information from books, periodicals, to farmers. The book and the periodicals published in Hindi, Bengali and other languages. The western part of India was prevalent with drought in 1887-1900 years. An American missionary published Indian Famine through Imperial Agricultural Research Institute (IARI), Pusa, Bihar. Then, Publication in agriculture was started in 1906 from Imperial Agricultural Research Institute 
(IARI). This institute started publication of the agriculture journal of India, the memoirs of the department of agriculture in India. This journal dealt about agriculture subject and scientific work. The publications and information divisions of the ICAR started another publication Indian journal of Agricultural Sciences that discussed agricultural research and Indian journal of veterinary sciences that imprinted animal husbandry in 1931. Kheti was begin in 1948 . The ICAR had started two research journals, three semi technical journals i.e. Kheti (monthly), phal phool (quarterly), Krishi chayanika (quarterly), ICAR reporter and ICAR news in 1973. The state agriculture universities like Ludhiana, Hisar, Jabalpur, Patna, Ranchi, Faizabad, Coimbatore, Hyderabad, private publishers, rural development organizations and Nongovernmental organization (NGO) had initiated periodicals and farm journalism in 1973 year. The journals, periodicals, Newsletter and farm magazines were nit ample to fulfill the requirement of farmers and employment generation.

The Times of India, The Hindu, The Business line and the Business standard initiated to provide agriculture report to farmers and the UNI started to provide daily agriculture news to farmers in mid-1973 year (Sharma, 1998). The technology was originated into agricultural journalism in India during 1973. The technology of mass communication was not progress because of less innovation in Science \& Technology.

The technology of communication like radio, television, telephone, computers and internet was innovated in $20^{\text {th }}$ century (David and Rene, 2006). This communication technology successfully provided employment and climate, weather, best framing system and market information to farmers (Raju and Malagatti, 2017).
The unemployment rate of India was $3.41 \%$ in $2014,3.51 \%$ in 2016 and $3.52 \%$ in 2017 . The unemployment rate has been projected $3.60 \%$ in 2020 (Statistic, 2017). The government sector and the private sector have confined into employment generation in India. These sectors are not ample to fulfill employment in future period. The agricultural journalism is an emerging means of employment in communication technology. Several profession areas of communication technology will generate employment to agricultural journalism into following ways i.e.

\section{Agriculture Radio Station}

Agriculture information and broadcasting

Implementation of autonomous agricultural journalism university and agricultural corporate

\section{Agriculture radio station}

Agriculture radio station is a novel sector to employment generation. This will generate employment into radio presenters, correspondents, programme facilitators, animateurs and intellectual resources. It would provide employment to scientists, subject matter specialists, rural trained farmers, skilled labours, unskilled labours another technical or non-technical position. The agriculture radio station should be implemented into main block of each district in India. The listener of rural people is more than urban people. Their primary occupation is agriculture for livelihood. The agricultural employee will quickly interact with remote farmers of each block, village and district. They will provide agriculture knowledge to farmers, highlighting problems of farmers and training to farmers. The appointed trained farmers would thrive agriculture development and social development of district block. 
A satellite digital radio and world space is a novel communication technology that utilizes in Asia and Africa. It broadcasts exclusively agriculture programme for farmers and generates employment for agricultural community. This communication was also established by Sri Lanka and UNESCO for agriculture development and to generate employment. The food and agriculture organization (FAO) had established communication centre to agriculture field activity and employment opportunity in North Ghana (Coldevin, 2000). The community audio tower systems (CATs) have been established 4000 rural areas in Philippines. This is also carried out in rural areas of Ethiopia, Thailand, Mozambique to mobilize agriculture information and employment generations (Dagron, 2001). The North Ghana has established Danish Community Development programme. This programme is broadcast from Daghou and Gonja villages. The community radio agriculture officers has been to agriculture extension programme, Its main objective to visit farmer community, prepare a series of discussion with local experts, a drama or a combination of techniques including interview with farmers in the field. The International service for National agriculture Research (INSAR) has initiated collaborative projects with university of Guelph, FAO and Canadian NGO. The aim of projects is to improve agriculture research, rural radio and employment opportunity. The institute has employed agriculture researchers and radio broadcaster to improve plan, preparation, format, evaluation of extension programme, provide training and improve farm radio broadcasting (Humbly and Kassam, 2002). The University of Ghana had started Wonsuom project in 18 villages. The mission of the project was to establish rural radio and focus on agriculture tropics, broadcast programme into six languages and employment opportunity. The appointed representative of extension officer, applicants of agricultural engineering and local NGO to prepare drama, drama script, magazine format, topical talk and discussion (Robert et al., 2003). The African broadcaster has initiated farm radio station. This station presents programme for African farming families and rural communities. It offers suggestion to counter poverty and food insecurity. It appoints trainer and experts that provide training or distance education (Farm Radio Company). The real agriculture radio station was established in Canada in 2008. This media offers information of current events, markets, agronomy, machinery, farm management and issue of agriculture. This information is drive by appointed presenter, experts and field editors (Real Agriculture).

Shuwael et al., (2005) experimented on mass media like radio, television, newspaper and magazines. They transmitted farm information of input supply, farm resources and general market information through mass media in Nigeria. They resulted that radio is most effective communication technology among all mass media. This communication is impacted greatly on production output, revenue and high employment opportunity.

\section{Agriculture information and broadcasting}

Agriculture information and broadcasting is a novel mass media that drives exclusive agriculture information to rural society through newspaper, magazines and television. It is a vehicle of agriculture technology transfer. Agriculture mass media plays imperative role in efficient dissemination of information. It delivers reliable and exact information to farmers for judging when or how to cultivate and harvest, what are management practices and when or where to sell (USAID, 2010). The agriculture information would discuss, observe, drive and mange by agriculture experts, scientist, field editors, editors, reviewers, correspondents, 
presenter and data surveyor. The appointed employment also functions in agriculture drama, script, agriculture current news, debate, agriculture problems, training, education, and agronomy and agriculture census. This mass media will generate massive opportunities in the agriculture sector. This mass media like magazine, newspaper and television would overcome a unemployment in current agriculture.

The agriculture information and Broadcasting should be established at every state in India. The agriculture magazine centre, agriculture newspaper press, and agriculture broadcasting centre will select agriculture degree holder. The agriculture information and the broadcasting would generate employment of editor, reviewer, correspondent, presenters, experts, scientists, analyzer and surveyor. The agriculture profession will function at block, village and district of the state. They would highlight agriculture current events, farmer problem, agriculture crops and farm machinery\& implements. This will progress crop production output, income, farmer life style and doubling of farmer income. It transmits information of modern agriculture technology, socio-economic characters of farmers, state agriculture, farmer's problems, current events, state or central agriculture subsidy and scheme, into rural societies within short time period.

This profession would function at block, village and district of the state. The technology of magazine press and newspaper press has been progressed in present period. The developed farmers are understood easily with pictures and simple language of magazines and newspaper. The mass media will progress state production methods and marketing of agriculture produce. Sylivia (2004) refers that mass media provide information to many people. Television and satellites dish are now available at rural areas that will disseminate agriculture rural programme. The farmers can easily understand the operation, technology and instruction through television. The NSSO and The ICRIER reported that progressive and non-progressive farmers are understand information of television as well as newspaper. It would presents age, marital status, educational qualification, farm size, farm family and annual income of farmers to fulfill need from state government and central government. The mass media will improve state production output and income. This special sector will overcome the unemployment in agriculture area.

The agriculture information and publication is tardy at rural area of Papua New Guinea. The agriculture information and publication system are ineffective in $85-93 \%$ of rural area. The government is urge to offer effective agriculture information and publication system at Papua New Guinea. This agriculture information and the publication system are contribute into food security, employment, income, reduce rural poverty and reduce food import (Agriculture.Org). The agriculture information and broadcasting executes knowledge and judgment of processed data. The information is enhanced and improves job productivity (Ezekiel and Peter, 2014). Ananta and Tauffique (2016) reported that media prepare women strong and empowers. It provides education, training and employment to women. The media, publication, market and advertisement offers employment to 4 million people in that 40 percent is skilled university graduates in Europe. The UK department of culture, media and sports offered 1.8 million jobs. Canada film and television generated full time employment (Gareth, 2009). The IT Company has initiated rural telecentre that functions for training, employment and information in Rawanda (Rosalind et al., 2014).

\section{Implementation of Agriculture Journalism University and Agriculture corporate}

The autonomous university and the corporate of agricultural journalism will be novel initiation into agriculture education and agriculture profession world. The deemed institution will offer Bachelor degree, Masters Degree and Ph.D. degree of agricultural journalism. It would conduct workshop, seminar, conference, 
project, mass media training or internship to exploration of students. This autonomous institution will conduct special research into mass media like agriculture newspaper, agriculture magazine, and agriculture farming census, farmer socio-economic data, and outreach of subsidy or scheme of state and central.

The agriculture corporate likes agriculture radio station, agriculture television, agriculture newspaper and agriculture magazines will be novel and distinct industry in agriculture mass communication. This corporate would function for training, internship and employment opportunity. This corporate would generate opportunity of agriculture presenter, editor, field editor, extension officer, expert, and scientist, and investigator etc, technical and non-technical areas.

The agriculture university and the agriculture corporate would be established into every state of India. These will produce gigantic employment in agriculture field. This will offer opportunity to state agriculture profession and non-agriculture profession also. They would appoint at block, village and district. This will bring agriculture education revolution, agriculture mass communication revolution and agriculture employment revolution in every state. This revolution thrive into state crop production, state GDP, state opportunity, farming system of farmer, lifestyle of farmers, overcome farmer problem and get scheme or subsidy benefits of state and central government.

The school of science and journalism of MU College of agriculture, food and natural resources offers education of agriculture journalism program. This school provides skills of public relation, market expert, advertisement, photographer, reporter, editor and freelance journalist. It provides opportunity with the collaboration of mass media corporate (dass.missouri.edu). The Princeton University offers education of agricultural journalism. This education provides aptitude of writing, advertisement, broadcasting, photojournalism, editing and design. It offers a variety of career opportunity with agricultural journalism (Princeton overview). The Agricultural Journalism Department of Texas University provides dexterity of computer labs, publication production, television, digital photography, audio laboratory and broadcast production. This institute offers training, internship and employment into corporate world (Texas University Report).

The G. B. Pant University of Agriculture and Technology, Patnagar called for action and implementation of agriculture journalism. The experts suggested that agriculture journalism will support in agriculture development of India. It transforms farming system of agriculture. The R\&D of Information and ICT resolve issue of agriculture system. It absorbs and acceptance by society at large number (Report, 2016).

Agriculture journalism is a novel sector of agriculture science. It will offer not only education but also generate opportunity for agriculture profession and non-agriculture profession. It improves and progresses national production, Gross Domestic Product (GDP), farming system, farmer problems, doubling of farmer income and unemployment. It will bring huge revolution into universities education system and mass media corporate. It would transforms agriculture aspects and scenario in India.

\section{References}

Agriculture.org, http://www.agriculture.org. $\mathrm{pg} / \mathrm{Ag} \% 20$ infor\%20Branch.htm.

Ananta, N. and Tauffiqu, A. 2016, Role of media in accelerating women empowerment. Int. J. $A d v$. Edu. Res., 1(1): 16-19.

Coldevin, G. 2000, Participatory communication and adult learning for rural development. J. Int. Communication, 7(2): 51-69. 
Dagron, A. 2001, Making waves: Stories of participatory Communication for Social Change. Rockefeller Foundation, New York, 1-258.

David, L. D. and Rene, P. M. 2006, What Are Agriculture Industry Professionals Trying to Tell Us? Implications for UniversityLevel Agricultural Communications Curricula. J. Appl. Comm., 90(3): 1-18.

Ezekiel, B. F., Ado-Ekiti, and Peter, O. O., 2014, An Assessment of the Use of Radio and other Means of Information Dissemination by the Residents of AdoEkiti, Ekiti-State, Nigeria. Library Philosophy and Practice, University of Nebraska-Lincoln, 1-30.

Farm Radio Company, about us, http://www.farmradio.org/about-us/.

Gareth, L. 2009, The Media and Development, What's the Story? The World Bank

Hambly, O. H. and Kassam, A. 2002, Listening to stakeholders: Agricultural research and rural Radio linkages. The Netherlands, ISNAR, 48.

Princeton Overview, agricultural-journalism, https://www.princetonreview.com/college -majors/13/agricultural-journalism.

Raju, K. and Malagatti, S. M., 2017, Agricultural journalism is an effective tool for farmers development in Dharwad district of Karnataka state. Rec. Res. Soc. Sci. Hum., 4(3): 66-70.

Real Agriculture, About us, Real Agriculture.com.

Report, 2016, National Workshop on Agricultural Journalism, Call for action: Recommendations \& Implementation Plan. G. B. Pant University of Agriculture \& Technology Pantnagar, Uttarakhand, 128.
Robert, C., Roger, B., Gordana, K. B. and Zakariah, A.B.T., 2003, Rural radio in agricultural extension: the example of vernacular radio programmes on soil and water conservation in $\mathrm{N}$. Ghana. Agricultural Research \& Extension Network, 127: 1-16.

Rosalind, Y., Loretta, de L., Vittorio, L., Lea, B. and Paola, V. 2014, Reporting on Rural Issues A Media Guide. International Labour Organization, International Labour Office. Dept. of Communication and Public Information, Italy, 1-44.

Science and Agricultural Journalism Program, MU College of Agriculture, Food and Natural Resources, http://dass.missouri. edu/agj/about/

Sharma, R. D., 1998, Growth of Agricultural Journalism and Agricultural Research Information Centre at ICAR. DESIDOC Bulletin of Information Technology, 18(2): 21-30.

Shuwa, M.I., Shettima, L., Makinta, B.G. and Kyari, A. 2014, Impact of mass media on farmers agricultural production, case study of Borno State, Agricultural Development Programme. Academia Journal of Scientific Research, 3(1): 008014.

Statistic, 2017, India - Unemployment rate, https://www.statista.com/statistics/27133 0/unemployment-rate-in-india.

Sylvia, B., 2004, Voices for Change. Rural Women and Communication. Communication for Development Group Extension, Education and Communication Service. FAO, Rome.

USAID, 2010, ICT to Enhance Farm Extension Service in Africa, Briefing Paper, November. Washington, D.C., 3-44.

\section{How to cite this article:}

Avinash Sharma, Monoj Sutradhar, Sheelawati Monlai and Nirupa Kumari. 2018. Agriculture Journalism Brings Employment in India. Int.J.Curr.Microbiol.App.Sci. 7(09): 2314-2319. doi: https://doi.org/10.20546/ijcmas.2018.709.287 